OPEN ACCESS

Edited by:

Mirko Basen,

University of Rostock, Germany

Reviewed by:

Wolfgang Buckel,

University of Marburg, Germany

Johann Heider

University of Marburg, Germany

${ }^{*}$ Correspondence: Nicolai Müller

Nicolai.Mueller@uni-konstanz.de

Specialty section:

This article was submitted to Microbial Physiology and Metabolism, a section of the journal

Frontiers in Microbiology

Received: 27 August 2019 Accepted: 15 November 2019 Published: 29 November 2019

Citation:

Keller A, Schink B and Müller N (2019) Energy-Conserving Enzyme Systems Active During Syntrophic Acetate Oxidation in the Thermophilic

Bacterium Thermacetogenium

phaeum. Front. Microbiol. 10:2785

doi: 10.3389/fmicb.2019.02785

\section{Energy-Conserving Enzyme Systems Active During Syntrophic Acetate Oxidation in the Thermophilic Bacterium Thermacetogenium phaeum}

\author{
Anja Keller ${ }^{1,2}$, Bernhard Schink ${ }^{1,2}$ and Nicolai Müller ${ }^{1 *}$ \\ ${ }^{1}$ Department of Biology, Universität Konstanz, Konstanz, Germany, ${ }^{2}$ Konstanz Research School Chemical Biology, \\ Konstanz, Germany
}

The thermophilic acetogen Thermacetogenium phaeum uses the Wood-Ljungdahl pathway (WLP) in both directions, either for the production of acetate from various compounds or for the oxidation of acetate in syntrophic cooperation with methanogens. In this study, energy-conserving enzyme systems in T. phaeum were investigated in both metabolic directions. A gene cluster containing a membrane-bound periplasmically oriented formate dehydrogenase directly adjacent to putative menaquinone synthesis genes was identified in the genome. The protein products of these genes were identified by total proteome analysis, and menaquinone MK-7 had been found earlier as the dominant quinone in the membrane. Enzyme assays with membrane preparations and anthraquinone-2,6-disulfonate as electron acceptor verified the presence of a quinonedependent formate dehydrogenase. A quinone-dependent methylene-THF reductase is active in the soluble fraction and in the membrane fraction. From these results we conclude a reversed electron transport system from methyl-THF oxidation to $\mathrm{CO}_{2}$ reduction yielding formate as reduced product which is transferred to the methanogenic partner. The redox potential difference between methyl-THF $\left(E_{0}{ }^{\prime}=-200 \mathrm{mV}\right.$ ) and formate $\left(E_{0}^{\prime}=-432 \mathrm{mV}\right)$ does not allow electron transfer through syntrophic formate removal alone. We postulate that part of the ATP conserved by substratelevel phosphorylation has to be invested into the generation of a transmembrane proton gradient by ATPase. This proton gradient could drive the endergonic oxidation of methyl-THF in an enzyme reaction similar to the membrane-bound reversed electron transport system previously observed in the syntrophically butyrate-oxidizing bacterium Syntrophomonas wolfei. To balance the overall ATP budget in acetate oxidation, we postulate that acetate is activated through an ATP-independent path via aldehyde:ferredoxin oxidoreductase (AOR) and subsequent oxidation of acetaldehyde to acetyl-CoA.

Keywords: syntrophic acetate oxidation, acetogenesis, methylene-THF reductase, membrane-bound formate dehydrogenase, Wood-Ljungdahl pathway 


\section{INTRODUCTION}

The Wood-Ljungdahl pathway (WLP) or reductive acetylCoA pathway is the central pathway in acetogens and most strictly anaerobic acetate-oxidizing bacteria (AOB). Although the WLP was investigated in depth the mechanism of energy conservation of most acetogens and $\mathrm{AOB}$ remained unclear since no net ATP is gained in this pathway by substrate level phosphorylation (Schuchmann and Müller, 2014). For Acetobacterium woodii, the mechanism of energy conservation was elucidated completely (Biegel et al., 2009, 2011; Biegel and Müller, 2010; Hess et al., 2013; Bertsch et al., 2015) and also the one in Moorella thermoacetica was studied in detail (Huang et al., 2012; Wang et al., 2013; Mock et al., 2014). A. woodii conserves energy with the help of a Rhodobacter nitrogen fixation (Rnf) complex which pumps sodium ions across the membrane while reduced ferredoxin $\left(\mathrm{Fd}^{2-}\right)$ is oxidized with $\mathrm{NAD}^{+}$in an exergonic reaction (Biegel and Müller, 2010). Other modes of energy conservation were hypothesized before. The thermophile $M$. thermoacetica was shown to have a heterohexameric methylene-THF reductase (MTHFR) (Mock et al., 2014) which does not catalyze the reduction of methyleneTHF with NADH. The genes for this enzyme are located in a cluster containing genes annotated as a heterodisulfide reductase (Hdr) enzyme complex. In the same study, it was proposed that the MTHFR could be coupled via formate dehydrogenase to the Ech hydrogenase, similar to a membrane-bound formate hydrogenlyase complex found in Escherichia coli. This system could be used to create a proton gradient across the membrane and thus conserve energy during acetogenesis (Mock et al., 2014). In contrast, A. woodii lacks this putatively proton translocating system and instead has a heterotrimeric NADHoxidizing methylene-tetrahydrofolate (THF) reductase which is not coupled to energy conservation (Bertsch et al., 2015).

Only little is known so far about the biochemistry of syntrophic acetate-oxidizing bacteria (SAOB). SAOB are hard to isolate and to cultivate. To date only six defined cultures are known (Schnürer et al., 1996; Hattori et al., 2000; Balk et al., 2002; Westerholm et al., 2010, 2011; Timmers et al., 2018). These cultures do not reach high cell densities, and investigations in cell-free systems are challenged with the problem that the SAOB have to be separated from their methanogenic partners to obtain cell suspensions containing only the bacterial component. One of the strains whose physiology was investigated in more detail is Clostridium ultunense, a mesophilic bacterium that oxidizes acetate in a triculture with a hydrogen- and formate-utilizing methanogen MAB1 and a further bacterium, strain TRX1 (Schnürer et al., 1996). The difficulties of mass cultivation for enzyme assays of syntrophic acetate oxidizers can be overcome by using proteomic and genomic approaches. A recent study compared the genomes of all defined SAOB co-cultures that have been sequenced so far (Manzoor et al., 2018).

For the present study, Thermacetogenium phaeum was chosen as a model organism for $\mathrm{SAOB}$ as its genome sequence is available. It poses a special case of $\mathrm{SAOB}$ due to its thermophilic lifestyle, with a temperature range between 40 and $65^{\circ} \mathrm{C}$ and an optimum growth temperature of $58^{\circ} \mathrm{C}$, that facilitates acetate conversion to $\mathrm{CO}_{2}$ and $\mathrm{CH}_{4}$ (Hattori et al., 2000; Oehler et al., 2012). T. phaeum is able to revert the WLP and thus oxidizes acetate in syntrophic cooperation with Methanothermobacter thermautotrophicus strain TM but uses as well hydrogen plus $\mathrm{CO}_{2}$ to form acetate in axenic cultures (Hattori et al., 2000, 2005). Recently, growth of T. phaeum with acetate, ethanolamine, methanol, and ethanol was characterized by proteomic analysis and enzyme assays (Keller et al., 2019). In the current study, the focus will be on syntrophic growth with acetate, and on axenic growth with formate or hydrogen plus $\mathrm{CO}_{2}$. Enzyme systems that are possibly involved in energy conservation such as membranebound formate dehydrogenases or hydrogenases as well as the MTHFR are studied in detail.

\section{MATERIALS AND METHODS}

\section{Origin of Organisms and Culture Conditions}

Axenic cultures of T. phaeum strain PB (DSM 26808) as well as the syntrophic co-culture with $M$. thermautotrophicus strain TM were obtained from the German Culture Collection (DSMZ, Braunschweig, Germany). Cultures were grown anaerobically in modified freshwater medium DSM880 as described before (Keller et al., 2019) at $55^{\circ} \mathrm{C}$ in the dark without shaking. The axenic culture of $T$. phaeum was grown with formate or hydrogen $/ \mathrm{CO}_{2}$, whereas the syntrophic co-culture was grown with acetate as substrate. Cultivation with hydrogen $/ \mathrm{CO}_{2}$ $(79 \% / 21 \% \mathrm{v} / \mathrm{v})$ was performed by flushing the headspace $(70 \mathrm{ml})$ of $150 \mathrm{ml}$ bottles for $1 \mathrm{~min}$ at an overpressure of 1 bar. Formate and acetate were autoclaved in $3 \mathrm{M}$ stock solutions and then added to the cultures to $40 \mathrm{mM}$ final concentration. Cultures were transferred at least 10 times [corresponding to approximately $22\left(\mathrm{H}_{2} / \mathrm{CO}_{2}\right)$ or 30 (formate) cell generations] with the respective substrates to assure complete adaptation before growth curves were recorded and proteome analysis was performed. For quantification of growth, four bottles were filled each with $45 \mathrm{ml}$ medium and $5 \mathrm{ml}$ pre-culture. Increase in optical density was monitored with a Jenway 6300 spectrophotometer (Staffordshire, United Kingdom) at $600 \mathrm{~nm}$. Substrate depletion and product formation was monitored by HPLC with a Shimadzu system as described before (Keller et al., 2019). Compounds were separated at $60^{\circ} \mathrm{C}$ on a Rezex ${ }^{\mathrm{TM}}$ RHM-Monosaccharide $\mathrm{H}^{+}(8 \%)$ ion exchange resin column (LC column $300 \times 7.8 \mathrm{~mm}, 00 \mathrm{H}-0132-\mathrm{K} 0$, Phenomenex, Los Angeles, CA, United States).

\section{Preparation of Cell-Free Extract and Subcellular Fractions}

The preparation of cell-free extracts and subcellular fractions for enzyme activity measurements was carried out under strictly anoxic conditions in an anoxic glove box (Coy, Ann Arbor, MI, United States). Centrifugation was performed in air-tight vessels, and buffers were made anoxic by alternately applying vacuum and $100 \% \mathrm{~N}_{2}$ three times under vigorous stirring. 
Cultures were harvested by centrifugation at 7,000 $\times g$ for $15 \mathrm{~min}$ at $4^{\circ} \mathrm{C}$ and washed once with $50 \mathrm{mM}$ Tris- $\mathrm{HCl}$ buffer, $\mathrm{pH}$ 7.5 , containing $3 \mathrm{mM}$ dithiothreitol (DTT). The co-culture was separated by a self-assembling Percoll gradient (70\% Percoll in distilled water containing $250 \mathrm{mM}$ sucrose) adapted from Luo et al. (2002) and Enoki et al. (2011) as described before (Keller et al., 2019). The gradient tubes were centrifuged for $1 \mathrm{~h}$ at $4^{\circ} \mathrm{C}$ at $45,000 \times g$ in a type $70-\mathrm{Ti}$ rotor in an Optima LE$80 \mathrm{~K}$ ultracentrifuge (Beckman Coulter, Brea, CA, United States). Cells of T. phaeum were enriched in the upper one of the two bands and the cells were collected and washed with $50 \mathrm{mM}$ Tris-HCl, pH 7.5, containing 3 mM DTT. Percoll-separated T. phaeum cells of syntrophic cultures or T. phaeum cells of axenic cultures were suspended in $3 \mathrm{ml}$ Tris- $\mathrm{HCl}$ buffer, $\mathrm{pH}$ 7.5 , containing $3 \mathrm{mM} \mathrm{DTT}$, and disrupted by at least three passages through a French pressure cell (Aminco, Silver Spring, $\mathrm{MD}$, United States) operated at $137 \mathrm{MPa}$. The crude extract was centrifuged at room temperature at $11,300 \times g$ for $5 \mathrm{~min}$ to clear it from cell debris and unopened cells. The soluble fraction containing cytoplasmic and periplasmic enzymes was obtained by ultracentrifugation at 100,000 $\times g$ in an Optima TLultracentrifuge using a TLA110-rotor (Beckman Coulter, Brea, CA, United States) for $1 \mathrm{~h}$. The pellet was washed once with $50 \mathrm{mM}$ Tris- $\mathrm{HCl}, \mathrm{pH} 7.5$, containing $3 \mathrm{mM}$ DTT, and after the second centrifugation the pellet was suspended in $0.8 \mathrm{ml}$ and defined as membrane fraction. The soluble fraction was further separated via an anion exchange column (Q-sepharose, HiTrapQ HP column, $5 \mathrm{ml}$, GE Healthcare, Pittsburgh, PA, United States) manually operated with syringes as described by Keller et al. (2019). First, $0.8 \mathrm{ml}$ of the soluble fraction was applied and the column was washed with five column volumes of $50 \mathrm{mM}$ Tris$\mathrm{HCl}, \mathrm{pH} 7.5$, containing $3 \mathrm{mM}$ DTT. Fraction 1 was eluted with two column volumes of Tris- $\mathrm{HCl}$ buffer containing additional $200 \mathrm{mM} \mathrm{NaCl}$ and then fraction 2 was eluted with Tris- $\mathrm{HCl}$ buffer containing $1 \mathrm{M} \mathrm{NaCl}$.

\section{Mass Spectrometry}

Mass spectrometry was performed at the Proteomics facility of the University of Konstanz as described before (Keller et al., 2019). The membrane fraction was cleared from interfering lipids by suspending the membrane pellet in 10\% SDS. The solubilized membrane pellet was mixed with loading dye (0.125 M Tris-HCl, pH 6.8, 2\% (w/v) SDS, 25\% glycerol, $0.01 \%(\mathrm{w} / \mathrm{v})$ bromophenolblue and $5 \% \beta$-mercaptoethanol) at a ratio of $1: 1$, heated to $98^{\circ} \mathrm{C}$ for $10 \mathrm{~min}$, and was run about $2 \mathrm{~cm}$ into a 12\% SDS gel (Laemmli, 1970). The gel was stained with colloidal Coomassie (Neuhoff et al., 1988; Schmidt et al., 2013) and the band containing the protein was excised. Samples were digested by trypsin treatment and analyzed by liquid chromatography nanospray tandem mass spectrometry (LC-MS/MS) using an Eksigent nano-HPLC and an LTQOrbitrap mass spectrometer (Thermo Fisher, Waltham, MA, United States) as described before (Keller et al., 2019). The ion chromatogram was analyzed using the Proteome Discoverer software (Thermo Fisher, Waltham, MA, United States) and the areas of the respective peaks were integrated for semi-quantitative analysis of relative protein abundances.

\section{Enzyme Activity Measurements}

All enzyme activity measurements were performed anoxically in glass cuvettes sealed with rubber stoppers which were flushed with $100 \% \mathrm{~N}_{2}$. Activity measurements were carried out at least in triplicate in a Jasco V630 or V730 spectrophotometer (Tokyo, Japan) at $55^{\circ} \mathrm{C}$ with $50 \mathrm{mM}$ Tris- $\mathrm{HCl}$ buffer, $\mathrm{pH} 7.5$, containing $3 \mathrm{mM}$ DTT if not stated otherwise.

\section{Formate Dehydrogenase}

Formate dehydrogenase was assayed according to Schmidt et al. (2014) and Keller et al. (2019). Electron acceptors used were either $0.5 \mathrm{mM}$ anthraquinone-2,6-disulfonate (AQDS) $\left[\varepsilon_{408}=7.2 \mathrm{mM}^{-1} \mathrm{~cm}^{-1}\right.$ (Liu et al., 2007; Shi et al., 2012)], $1 \mathrm{mM}$ benzyl viologen (BV) [BV: $\varepsilon_{578}=8.65 \mathrm{mM}^{-1} \mathrm{~cm}^{-1}$ (McKellar and Sprott, 1979)], $0.25 \mathrm{mM} \mathrm{NAD}^{+}\left[\varepsilon_{340}=6.3 \mathrm{mM}^{-1} \mathrm{~cm}^{-1}\right.$ (Ziegenhorn et al., 1976)] or $16 \mu \mathrm{M}$ oxidized ferredoxin $\left(\mathrm{Fd}_{\mathrm{ox}}\right)$ $\left[\varepsilon_{390}=30 \mathrm{mM}^{-1} \mathrm{~cm}^{-1}\right.$ (Gersonde et al., 1971)]. Reduction of AQDS was monitored at $408 \mathrm{~nm}$, of BV at $578 \mathrm{~nm}$, of $\mathrm{NAD}^{+}$at $340 \mathrm{~nm}$ and of $\mathrm{Fd}_{\text {ox }}$ at $390 \mathrm{~nm}$. Reactions were started by addition of $5 \mathrm{mM}$ sodium formate.

\section{Hydrogenases}

Hydrogenases were measured analogous to formate dehydrogenase with the electron acceptors $0.5 \mathrm{mM}$ AQDS, $1 \mathrm{mM} \mathrm{BV} 0.25 \mathrm{mM} \mathrm{NAD}^{+}$and $16 \mu \mathrm{M} \mathrm{Fd}_{\mathrm{ox}}$. The reaction was started by injection of $100 \mu \mathrm{l}$ hydrogen into the head space according to Keller et al. (2019).

\section{NADH:Acceptor Oxidoreductase}

NADH:acceptor oxidoreductase was measured with $0.5 \mathrm{mM}$ $\mathrm{NADH}$ and $0.5 \mathrm{mM}$ AQDS. To monitor the reaction, reduction of AQDS was followed at $408 \mathrm{~nm}$. Formate dehydrogenase, hydrogenase and $\mathrm{NADH}$ :acceptor oxidoreductase activity were measured in soluble and membrane fractions of T. phaeum cells grown in syntrophic co-culture with acetate.

\section{Methylene-THF Reductase (MTHFR)}

Methylene-THF reductase was measured with $0.25 \mathrm{mM} \mathrm{NADH}$ or $0.25 \mathrm{mM}$ NADPH as electron donor and methylene-THF as electron acceptor which was synthesized directly in the buffer as described in detail in Bertsch et al. (2015). For this purpose, $1.5 \mathrm{mM}$ formaldehyde and $0.5 \mathrm{mM}$ THF were

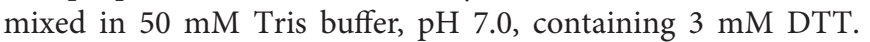
Controls with formaldehyde alone were performed to rule out side reactions such as methanol dehydrogenase. To examine an electron bifurcation function of the MTHFR $16 \mu \mathrm{M} \mathrm{Fd} \mathrm{dx}_{\mathrm{ox}}$ was added to $0.25 \mathrm{mM} \mathrm{NADH}$ and oxidation of $\mathrm{NADH}$ was monitored. Oxidation of NADH and NADPH was followed at $365 \mathrm{~nm}\left[\varepsilon_{365}=3.441 \mathrm{mM}^{-1} \mathrm{~cm}^{-1}\right.$ (Ziegenhorn et al., 1976)]. Furthermore, the MTHFR was assayed with $0.2 \mathrm{mM}$ methylTHF and $0.5 \mathrm{mM} \mathrm{NAD}^{+}, 1 \mathrm{mM} \mathrm{BV}$ and $0.5 \mathrm{mM}$ AQDS as electron acceptors modified after (Rosner and Schink, 1995; Bertsch et al., 2015). The enzyme was assayed in $50 \mathrm{mM}$ Tris buffer, $\mathrm{pH} 7.5$, containing $3 \mathrm{mM}$ DTT, and the reaction was started by addition of methyl-THF. NAD ${ }^{+}$reduction was monitored at $340 \mathrm{~nm}\left[\varepsilon_{340}=6.3 \mathrm{mM}^{-1} \mathrm{~cm}^{-1}\right.$ (Ziegenhorn et al., 1976)], BV reduction at $578 \mathrm{~nm}\left[\mathrm{BV}: \varepsilon_{578}=8.65 \mathrm{mM}^{-1} \mathrm{~cm}^{-1}\right.$ 
(McKellar and Sprott, 1979)], and AQDS reduction at $408 \mathrm{~nm}$ [ $\varepsilon_{408}=7.2 \mathrm{mM}^{-1} \mathrm{~cm}^{-1}$ (Liu et al., 2007; Shi et al., 2012)].

\section{Methylene-THF Dehydrogenase (MTHFD)}

Methylene-THF dehydrogenase was assayed with $0.25 \mathrm{mM}$ $\mathrm{NAD}^{+}$and $0.25 \mathrm{mM} \mathrm{NADP}{ }^{+}$as electron acceptors and methylene-THF as electron donor, which was synthesized as described above. The reduction of $\mathrm{NAD}^{+}$and $\mathrm{NADP}^{+}$was monitored at $365 \mathrm{~nm}$. Activities of MTHFR and MTHFD were assayed in the soluble fraction and its subfractions 1 and 2, as well as in the membrane fractions of acetate-grown cells.

\section{Comparison of Gene Clusters}

The methylene-THF encoding gene clusters of $A$. woodii WB1 (DSM 1030), M. thermoacetica (ATCC 39073) and T. phaeum $\mathrm{PB}$ (DSM12270) as well as the gene cluster containing the periplasmically oriented formate dehydrogenase of $T$. phaeum and Syntrophomonas wolfei Goettingen (DSM2245B) were compared with the help of the IMG genome BLAST tool ${ }^{1}$ using the blastp program comparing amino acid sequences. Transmembrane domains were predicted with TMHMM (v.2.0, $(\mathrm{URL})^{2}$, and signal peptides were predicted with SignalP $5.0^{3}$. Selenocysteine insertion motifs were identified using the bSECISearch tool (Zhang and Gladyshev, 2005) .

\section{RESULTS}

\section{Growth With Formate or Hydrogen/ $\mathrm{CO}_{2}$}

Axenic cultures of $T$. phaeum were grown with $40 \mathrm{mM}$ formate or hydrogen $/ \mathrm{CO}_{2}$, respectively. For growth with hydrogen $/ \mathrm{CO}_{2}$ (79\%/21\%) the headspace of the bottles was flushed for $1 \mathrm{~min}$. As described earlier (Keller et al., 2019), syntrophic cultures of $T$. phaeum with $M$. thermautotrophicus grown with $40 \mathrm{mM}$ acetate needed 21 days to reach early stationary phase with a doubling time of $42 \mathrm{~h}$ as described before (Keller et al., 2019). Cultures grown with formate needed 8 days and with hydrogen $/ \mathrm{CO}_{2} 5$ days to reach stationary phase, with doubling times of 25 to $30 \mathrm{~h}$ during exponential growth phases. Growth was very poor and the average change in $\mathrm{OD}_{600}$ was 0.042 for hydrogen $/ \mathrm{CO}_{2}$ which, however, could be increased by flushing the headspace again with hydrogen/ $\mathrm{CO}_{2}$. Cultures grown with formate reached an average $\mathrm{OD}_{600}$ of 0.07 (Figure 1).

\section{Total Proteome Analysis}

Total proteome analysis was done with both the soluble fraction and the membrane fraction after syntrophic growth with acetate and growth with formate or hydrogen $/ \mathrm{CO}_{2}$ (Supplementary Table S1). All four hydrogenase systems and one formate hydrogenlyase system (FHL) encoded in the genome (Oehler et al., 2012) were identified in the proteome at different levels of abundance (Figure 2). Non- $\mathrm{F}_{420}$-reducing hydrogenase

\footnotetext{
${ }^{1}$ https://img.jgi.doe.gov/cgi-bin/m/main.cgi

${ }^{2}$ http://www.cbs.dtu.dk/services/TMHMM/

${ }^{3}$ http://www.cbs.dtu.dk/services/SignalP/

${ }^{4}$ http://genomics.unl.edu/bSECISearch
}

(gene locus tags Tph_c26910-26930), membrane-bound Ech hydrogenase (Tph_c21310-21360), NAD(P)-dependent irononly hydrogenase (Tph_c18430- 18460) and a periplasmic [NiFeSe] hydrogenase (Tph_c06350- 06370) were identified in the proteome during growth with acetate, formate, and hydrogen $/ \mathrm{CO}_{2}$ (Figure 2). A FHL was present during growth with hydrogen/ $/ \mathrm{CO}_{2}$. This FHL system comprises 9 subunits (Tph_c26250- c26370). These subunits are two formate dehydrogenase subunits (Tph_c26250- c_26260), two FHL subunits (Tph_c26270, Tph_c26330) and five hydrogenase-4 (FHL) subunits (Tph_c26280- c26300, Tph_c26340- c26350). Besides the formate dehydrogenase genes present in the FHL cluster, there are five more formate dehydrogenase genes encoded in the genome of $T$. phaeum. The formate dehydrogenase (Tph_18420) whose gene is located next to the one of an NAD(P)-dependent iron-only hydrogenase was present in the proteome during growth with all three substrates. Two formate dehydrogenase gene clusters (Tph_c21680-21660, Tph_c08060- 08040) were found to be located next to genes annotated as a putative NADH:quinone oxidoreductase. One of the latter formate dehydrogenase gene clusters (Tph_c2168021660) was apparently not expressed under the applied growth conditions as the respective proteins were not identified in the proteome. The gene cluster of the other formate dehydrogenase (Tph_c08060-08040) was only partially expressed during growth with acetate but constitutively expressed during growth with formate and hydrogen/ $\mathrm{CO}_{2}$ as judged from the presence of the respective proteins. Another formate dehydrogenase (Tph_c27290) was present only during growth with acetate at a very low level, however, in an earlier study, this protein was found to be moderately abundant during syntrophic growth with ethanol or ethanolamine (Keller et al., 2019). Membrane-bound formate dehydrogenase (Tph_c15380-15410) was identified in the proteome during growth with acetate and not during growth with formate or hydrogen. Enzymes of the WLP were present in the proteome during growth with formate or hydrogen $/ \mathrm{CO}_{2}$ (Figure 3). The presence of all enzymes of the WLP during growth with acetate was shown before (Keller et al., 2019).

\section{Analysis of the Methylene-THF Reductase Gene Cluster}

The genes for the enzymes of the WLP were found to be clustered in two different locations in the genome of T. phaeum. The first cluster contains genes for MTHFD and cyclohydrolase (Tph_c16310- Tph_16320). The amino acid sequence of the two subunits of the enzyme combining MTHFD and cyclohydrolase activity exhibit 50\% (Tph_c16320) and 54\% identity (Tph_c16310) compared to the ones of M. thermoacetica. Identities with the homologs in A. woodii are substantially lower, with $35 \%$ and $29 \%$, respectively. The second cluster contains the genes encoding CODH/ACS (structural precursor genes and their maturation factors; Tph_c15140- Tph_c15190), methyl-tetrahydrofolate-corrinoid iron-sulfur protein Co-methyltransferase (Tph_c15130) and MTHFR (Tph_c15100- Tph_c15110). MTHFR subunits of T. phaeum show high similarity to the MetF (Tph_c15100, 39\% 

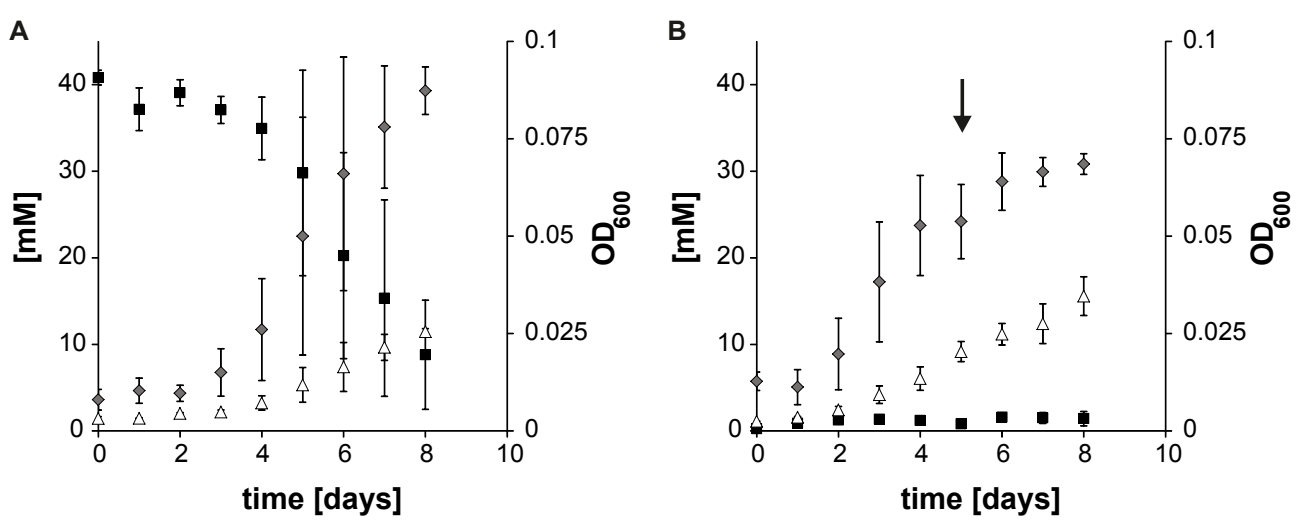

FIGURE 1 | Growth curves of Thermacetogenium phaeum depicting substrate depletion, product formation, and $\mathrm{OD}_{600}$ increase. (A) Axenic growth with formate. (B) Axenic growth with hydrogen $/ \mathrm{CO}_{2}$. The arrow marks the time point when the culture was refed with $\mathrm{H}_{2} / \mathrm{CO}_{2}$. Gray diamonds depict OD 600 , black squares depict formate concentration and white triangles depict acetate. All concentrations are given in $\mathrm{mM} \pm$ standard deviation.

identity) and MetV (Tph_c15110 34\% identity) of A. woodii (Table 1; Keller et al., 2019). When comparing the gene clusters of $A$. woodii and $M$. thermoacetica, differences in the composition of this gene cluster can be observed (Figure 4). Compared to $A$. woodii, T. phaeum lacks the gene that is annotated as $r n f C 2$ and its product was postulated as the NADHbinding subunit of the MTHFR in A. woodii (Bertsch et al., 2015; Keller et al., 2019). Analogous to $M$. thermoacetica, in T. phaeum, an $h d r A$ gene is located in the gene cluster directly adjacent to the MTHFR. The amino acid sequences of HdrA are identical to $31 \%$. Furthermore, there is a coenzyme $\mathrm{F}_{420}$ reducing hydrogenase subunit (Tph_c15120) that shows $40 \%$ identity to the one of $M$. thermoacetica. These two enzymes are not present in A. woodii. The genes for the subunits $\mathrm{HdrB}$ and $\mathrm{HdrC}$ present in $M$. thermoacetica are not located in the methylene-THF containing gene cluster of T. phaeum. However, there is a gene coding for an HdrB (Tph_c15470) subunit whose amino acid sequence has an identity of $42 \%$ and a gene for an HdrC (Tph_c15480) subunit whose amino acid sequence has an identity of $36 \%$ to the one of $M$. thermoacetica in a different gene cluster next to a formate dehydrogenase gene and to the quinone synthesis genes.

\section{Analysis of a Putatively Periplasmically Oriented Formate Dehydrogenase Gene Cluster}

During growth with acetate, the genes coding for a membranebound formate dehydrogenase (Tph_c15370- c15410) were expressed. Genes coding for this enzyme system were found to be located next to quinone synthesis genes (Tph_c15430c15460), to two genes of subunits of a heterodisulfide reductase ( $h d r B$ and $h d r C$, Tph_c15470-Tph_c15480) and to one gene of a subunit of a sec-independent TAT translocase (tat $C$, Tph_c15420) (Figure 4). Another gene for a subunit of the TAT translocase complex can be found elsewhere in the genome and is located next to the gene coding for Ech hydrogenase (tatA, Tph_c21300). The formate dehydrogenase complex consists of two genes coding for subunits containing trans-membrane helices; first a formate dehydrogenase gamma subunit gene (Tph_c15380) and second a quinone-dependent subunit gene (Tph_c15390). One of the remaining two subunit genes (fdhA2, Tph_c15410) carries a signal sequence for the Twin-arginine translocation pathway which is lacking in the other subunit (analyzed with SignalP 5.0 and automatic annotation in IMG). A selenocysteine insertion sequence (SECIS)-search of the nucleotide sequence of $f d h A 2$ (Tph_c15410) revealed that the proteins of this gene and the protein of the adjacent gene $f d h A 1$ coding for a large formate dehydrogenase subunit (Tph_c15400) are linked through selenocysteine incorporation, meaning that these two genes are translated into one single protein (Zhang and Gladyshev, 2005). In contrast to Oehler et al. (2012), we therefore suggest that this formate dehydrogenase complex is membrane bound, and that the fused protein of the genes fdhA1 and fdhA2 (Tph_c15400 and Tph_c15410) is located at the periplasmically oriented side of the enzyme complex. Consequently, the complete formate dehydrogenase complex consists of three protein subunits, namely two proteins with transmembrane helices (Tph_c15380 and fdh subunit gamma, Tph_c15390) and one large periplasmic subunit. The protein of the gene annotated as $f d h E$ (Tph_c15370) is responsible for maturation of the formate dehydrogenase complex. Analysis of the gene neighborhood of the quinone-dependent formate dehydrogenase (Tph_c15390) with the same COG hit in IMG showed similarity with the respective gene neighborhood in S. wolfei and Syntrophomonas zehnderi. Yet, these strains do not have a heterodisulfide reductase encoded in the same gene cluster. In an IMG gene neighborhood search with this heterodisulfide reductase beta subunit, Syntrophaceticus schinkii shows the highest similarity. If the amino acid sequence of heterodisulfide reductase is searched against the genome of S. wolfei with the IMG BLAST tool, it shows $47 \%$ identity for the beta subunit and $43 \%$ for the HdrC subunit. The amino acid sequences of the formate dehydrogenase subunits FdhA1 (Tph_c15400, Swol_0799) showed 56\% similarity and FdhA2 (Tph_c15410, Swol_0800) showed 53\%, the iron-sulfur 


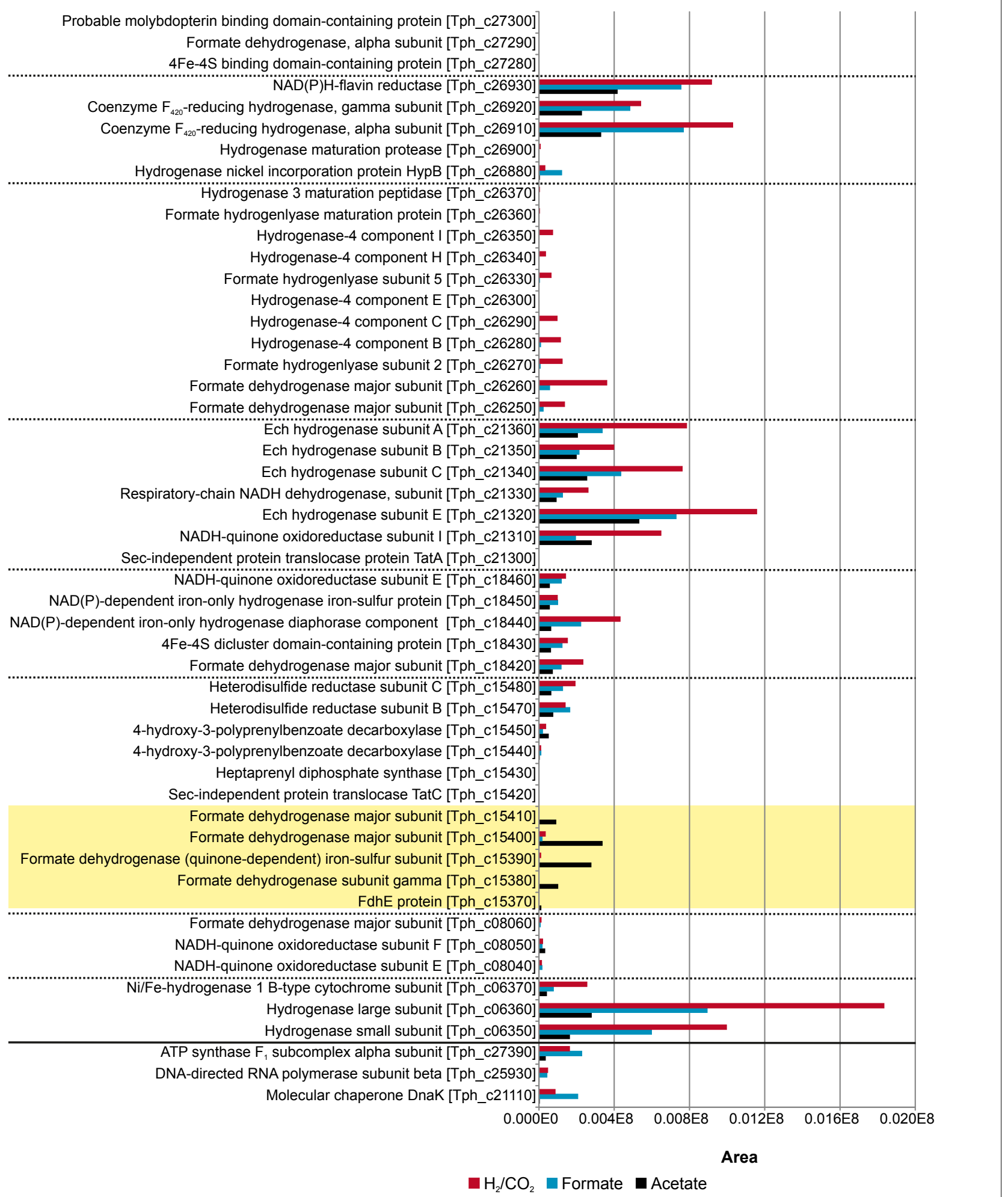

FIGURE 2 | Proteome data of all formate hydrogenases and hydrogenases obtained during growth of T. phaeum with formate, hydrogen/CO expressed genes of the different gene clusters are shown in the graph. The clusters are separated by dashed lines. Proteins of the membrane bound, periplasmically oriented formate dehydrogenase that are dominantly present during syntrophic growth with acetate are highlighted in yellow. Housekeeping proteins are depicted beneath the solid line. The proteome data for cultivation with acetate is taken from Keller et al. (2019). The relative abundance of the respective proteins was semi-quantitatively analyzed using the area values of the corresponding peaks of the ion chromatogram and using the Proteome Explorer software (Thermo Fisher). Shown are non-normalized area values in relation to area values of housekeeping proteins (ATPase, RNA-polymerase and molecular chaperone DnaK). 


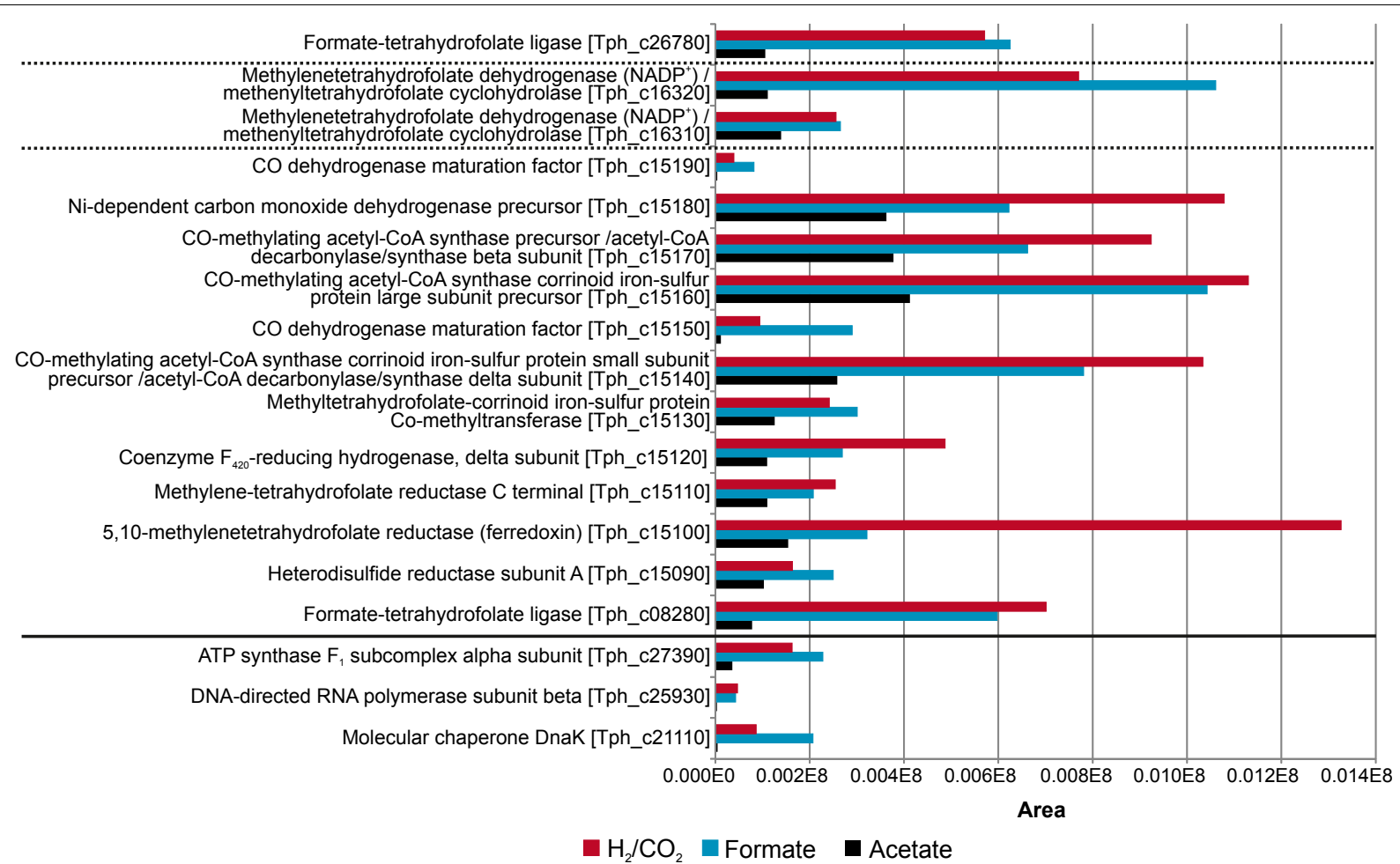

FIGURE 3 | Proteome data of all enzymes of the Wood-Ljungdahl pathway (WLP) obtained during growth of T. phaeum with formate, hydrogen/CO 2 , and acetate. The clusters are separated by dashed lines. Housekeeping proteins are depicted beneath the solid line. The proteome data for cultivation with acetate is taken from Keller et al. (2019). The relative abundance of the respective proteins was semi-quantitatively analyzed using the area values of the corresponding peaks of the ion chromatogram and using the Proteome Explorer software (Thermo Fisher). Shown are non-normalized area values in relation to area values of housekeeping proteins (ATPase, RNA-polymerase and molecular chaperone DnaK).

subunit (Tph_c15390,Swol_0798) had 54\%, the gamma subunit (Tph_c15380, Swol_0797) 46\% and the formate accessory protein (Tph_c15370, Swol_0796) had only 28\% identity. In contrast to the iron-sulfur subunit (Tph_c15390), its homolog in S. wolfei (Swol_0796) does not have transmembrane helices. M. thermoacetica was shown to have a periplasmically oriented formate dehydrogenase (gene locus tags Moth_04500452) as well. The amino acid sequences of the major subunit (Moth_0450) showed 23 to 30\% identity to the major subunits (Tph_c15400-15410) of the periplasmically oriented formate dehydrogenase of T. phaeum. The iron-sulfur complex containing subunit (Moth_0451) exhibits 30\% identity with the quinone-dependent subunit (Tph_c15390) of T. phaeum and the gamma subunit (Moth_0452) shows 33\% identity to the gamma subunit (Tph_c15380) of T. phaeum.

\section{Activities of Key Enzymes \\ Methylene-THF Reductase (MTHFR) and Methylene-THF Dehydrogenase (MTHFD)}

Activities of MTHFR and MTHFD were assayed photometrically in the following subcellular fractions: membrane fraction, soluble fraction, and fraction 1 and 2 which were soluble fractions eluted from an anion exchange column with $200 \mathrm{mM} \mathrm{NaCl}$ or $1 \mathrm{M}$ $\mathrm{NaCl}$, respectively. MTHFR was measured with methylene-THF and $\mathrm{NADH}$ or NADPH as electron donors in the direction of methyl-THF formation. Activity with NADH was observed only in fraction 2 (Table 2), which is most likely due to the presence of MTHFD in the soluble fraction which immediately reduces the produced $\mathrm{NAD}^{+}$through oxidation of methyleneTHF. Therefore, both MTHFR and MTHFD have to be separated to properly assess their individual activity with methylene-THF. No activity was observed with NADPH. Addition of $\mathrm{Fd}_{\mathrm{ox}}$ that was purified from Clostridium pasteurianum did not lead to increased activity. This test was run to check for a possible bifurcating enzyme reaction that could enable endergonic oxidation of methyl-THF with $\mathrm{NAD}^{+}$by exergonic oxidation of reduced ferredoxin with another molecule of $\mathrm{NAD}^{+}$. MTHFR was measured also in the oxidative direction with methyl-THF and $\mathrm{NAD}^{+}$, benzyl viologen (BV) or anthraquinone-2,6-disulfonate (AQDS) as electron acceptor. No activity of the MTHFR was observed for methyl-THF oxidation with $\mathrm{NAD}^{+}$in the soluble or membrane fraction. Instead, methyl-THF oxidizing enzyme activity was found with the artificial electron acceptors BV and AQDS and can therefore be considered as $\mathrm{NAD}^{+}$-independent. The highest activity with benzyl viologen was detected in the membrane fraction with $2598 \mathrm{mU} / \mathrm{mg}$ protein and the second highest one in fraction 2 with $477 \mathrm{mU} / \mathrm{mg}$ protein. Activities with the artificial quinone-analogous acceptor AQDS were generally lower and in the range of $4 \mathrm{mU} / \mathrm{mg}$ protein (membrane fraction) to $24 \mathrm{mU} / \mathrm{mg}$ protein (soluble fraction). 
TABLE 1 | Comparison of genes of the cluster coding for CODH and MTHFR of Thermacetogenium phaeum to genes of Moorella thermoacetica and Acetobacterium woodii.

\begin{tabular}{|c|c|c|c|c|c|}
\hline \multirow[t]{2}{*}{ Gene name } & \multirow{2}{*}{$\frac{\text { T. phaeum }}{\text { Locus tag Tph_c }}$} & \multicolumn{2}{|c|}{ M. thermoacetica } & \multicolumn{2}{|c|}{ A. woodii } \\
\hline & & Locus tag Moth_ & Identity [\%] & Locus tag Awo_c & Identity [\%] \\
\hline Hypothetical protein & 15080 & No identity & & No identity & \\
\hline Heterodisulfide reductase subunit A & 15090 & 1194 & 31 & No identity & \\
\hline $\begin{array}{l}\text { 5,10-methylene-tetrahydrofolate reductase } \\
\text { (ferredoxin) }\end{array}$ & 15100 & 1191 & 66 & 09310 & 39 \\
\hline Methylene-tetrahydrofolate reductase C terminal & 15110 & 1192 & 55 & $\begin{array}{l}09290 \\
09300\end{array}$ & $\begin{array}{l}38 \\
34\end{array}$ \\
\hline $\begin{array}{l}\text { Coenzyme } \mathrm{F}_{420} \text {-reducing hydrogenase, delta } \\
\text { subunit }\end{array}$ & 15120 & 1193 & 40 & 10560 & 31 \\
\hline $\begin{array}{l}\text { Methyl-tetrahydrofolate-corrinoid iron-sulfur protein } \\
\text { Co-methyltransferase }\end{array}$ & 15130 & 1197 & 62 & 10730 & 39 \\
\hline $\begin{array}{l}\text { CO-methylating acetyl-CoA synthase corrinoid } \\
\text { iron-sulfur protein small subunit } \\
\text { precursor/acetyl-CoA decarbonylase/synthase } \\
\text { delta subunit }\end{array}$ & 15140 & 1198 & 57 & 10710 & 37 \\
\hline CO dehydrogenase maturation factor & 15150 & 1199 & 57 & $\begin{array}{l}10670 \\
10750\end{array}$ & $\begin{array}{l}46 \\
32\end{array}$ \\
\hline $\begin{array}{l}\text { CO-methylating acetyl-CoA synthase corrinoid } \\
\text { iron-sulfur protein large subunit precursor }\end{array}$ & 15160 & 1201 & 58 & 10720 & 42 \\
\hline $\begin{array}{l}\text { CO-methylating acetyl-CoA synthase } \\
\text { precursor/acetyl-CoA decarbonylase/synthase beta } \\
\text { subunit }\end{array}$ & 15170 & 1202 & 59 & 10760 & 44 \\
\hline $\begin{array}{l}\text { Ni-dependent carbon monoxide dehydrogenase } \\
\text { precursor }\end{array}$ & 15180 & 1203 & 57 & 10740 & 40 \\
\hline CO dehydrogenase maturation factor & 15190 & 1204 & 56 & 10750 & 42 \\
\hline
\end{tabular}

Comparison was performed with the IMG genome BLAST tool.

MTHFD was measured with methylene-THF and $\mathrm{NAD}^{+}$and $\mathrm{NADP}^{+}$as electron acceptors. Here, the activity with $\mathrm{NAD}^{+}$was 10,000 fold higher than with $\mathrm{NADP}^{+}$and was mainly found in fraction 1. A control experiment with formaldehyde was performed since methylene-THF was synthesized directly in the buffer by addition of THF and formaldehyde. The highest activity here was $5 \mathrm{mU} / \mathrm{mg}$ protein in the soluble fraction with NADH.

\section{Electron-Carrier Re-oxidizing Enzyme Systems}

In an attempt to identify enzyme systems that terminally transfer electrons to protons to release hydrogen or transfer electrons to protons and $\mathrm{CO}_{2}$ to release formate, activities of NADH:acceptor oxidoreductase, formate dehydrogenase, and hydrogenase were tested with photometric enzyme assays. An NADH:acceptor oxidoreductase was measured only in the soluble fraction with an activity of $95 \mathrm{mU} / \mathrm{mg}$ protein and with the quinone-like artificial electron acceptor AQDS. Activities of formate dehydrogenase and hydrogenase were measured with various electron acceptors (Table 3). Formate dehydrogenase showed very little activity with $\mathrm{NAD}^{+}(5 \mathrm{mU} / \mathrm{mg}$ protein) only in the soluble fraction and not in the membrane fraction. There was no reaction with $\mathrm{Fd}_{\mathrm{ox}}$. Activity of formate dehydrogenase with AQDS was distributed evenly between soluble fraction $(554 \mathrm{mU} / \mathrm{mg}$ protein) and membrane fraction (283 $\mathrm{mU} / \mathrm{mg}$ protein), whereas activity with benzyl viologen was found mainly in the soluble fraction $(12234 \mathrm{mU} / \mathrm{mg}$ protein in the soluble fraction and $1866 \mathrm{mU} / \mathrm{mg}$ protein in the membrane fraction). From these results, formate dehydrogenase can be considered an $\mathrm{NAD}^{+}$-independent enzyme. Activity of hydrogenase with $\mathrm{NAD}^{+}$was almost evenly distributed between soluble and membrane fraction. No activity of the hydrogenase was observed with $\mathrm{Fd}_{\mathrm{ox}}$. When tested with benzyl viologen and AQDS, activities of hydrogenase were found to be enriched in the membrane fraction compared to the soluble fraction.

\section{DISCUSSION}

In the present study, $T$. phaeum was grown axenically with hydrogen $/ \mathrm{CO}_{2}$ or formate as well as in a syntrophic coculture with acetate. All genes of the WLP were found to be expressed during growth with the used substrates. Thus, we confirm that in T. phaeum the WLP is used in both directions, depending on the substrate provided (Hattori et al., 2005). In the following part we discuss the enzymes which were prominently induced and thus were putatively connected to energy conservation under the respective growth condition.

\section{Acetogenic Growth With Hydrogen/ $\mathrm{CO}_{2}$ or Formate}

The only acetogen for which the mechanism of energy conservation during growth with hydrogen $/ \mathrm{CO}_{2}$ was unraveled 


\section{Moorella thermoacetica (A)}

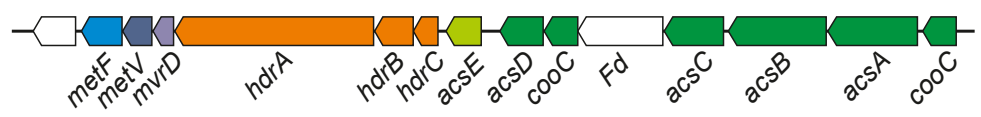

Thermacetogenium phaeum (B)

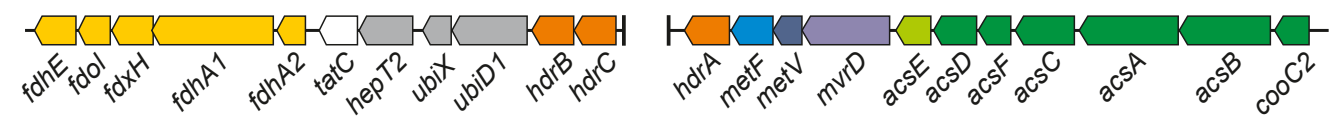

Acetobacterium woodii (C)



(A) and (B)

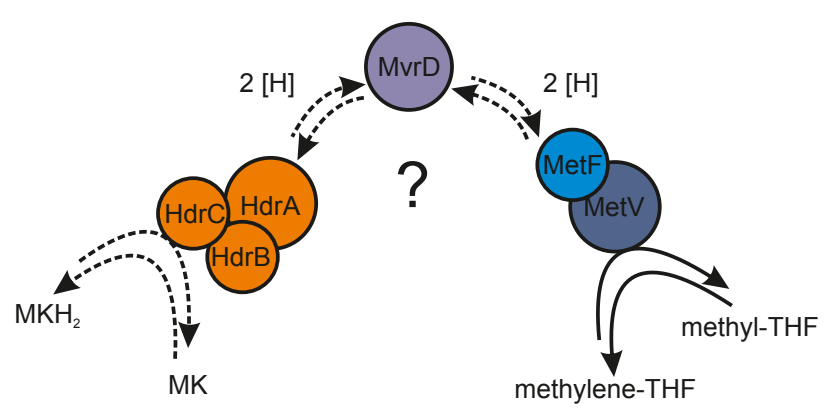

(C)

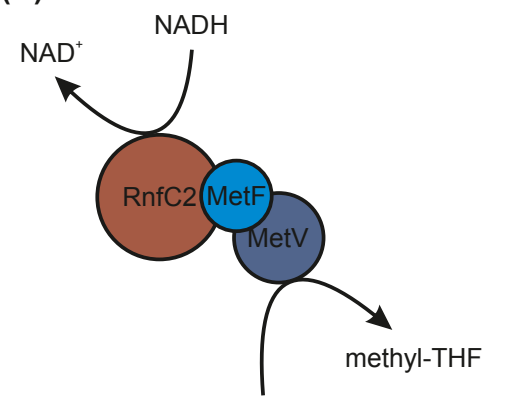

methylene-THF

FIGURE 4 | Comparison of the organization of the gene cluster containing the CODH/ACS-encoding genes and the genes for MTHFR of T. phaeum with the corresponding gene clusters of $M$. thermoacetica and Acetobacterium woodii. The proposed system for the electron transfer of the MTHFR in T. phaeum and M. thermoacetica is depicted in (A) and (B) and the protein complex responsible for methylene-THF reduction in A. woodii is depicted in (C) [adapted from Bertsch et al. (2015)]. MK, oxidized menaquinone; $\mathrm{MKH}_{2}$, menaquinol; MvrD, methyl-viologen-reducing hydrogenase subunit $\mathrm{D}$; the native electron carrier is still unknown and MvrD is one potential candidate (labeled with a question mark). Activities of MTHFR described in this study were measured with artificial electron acceptors.

TABLE 2 | Activities of methylene-THF reductase and methylene-THF dehydrogenase measured with various electron acceptors in different subcellular fractions of cells grown syntrophically with acetate.

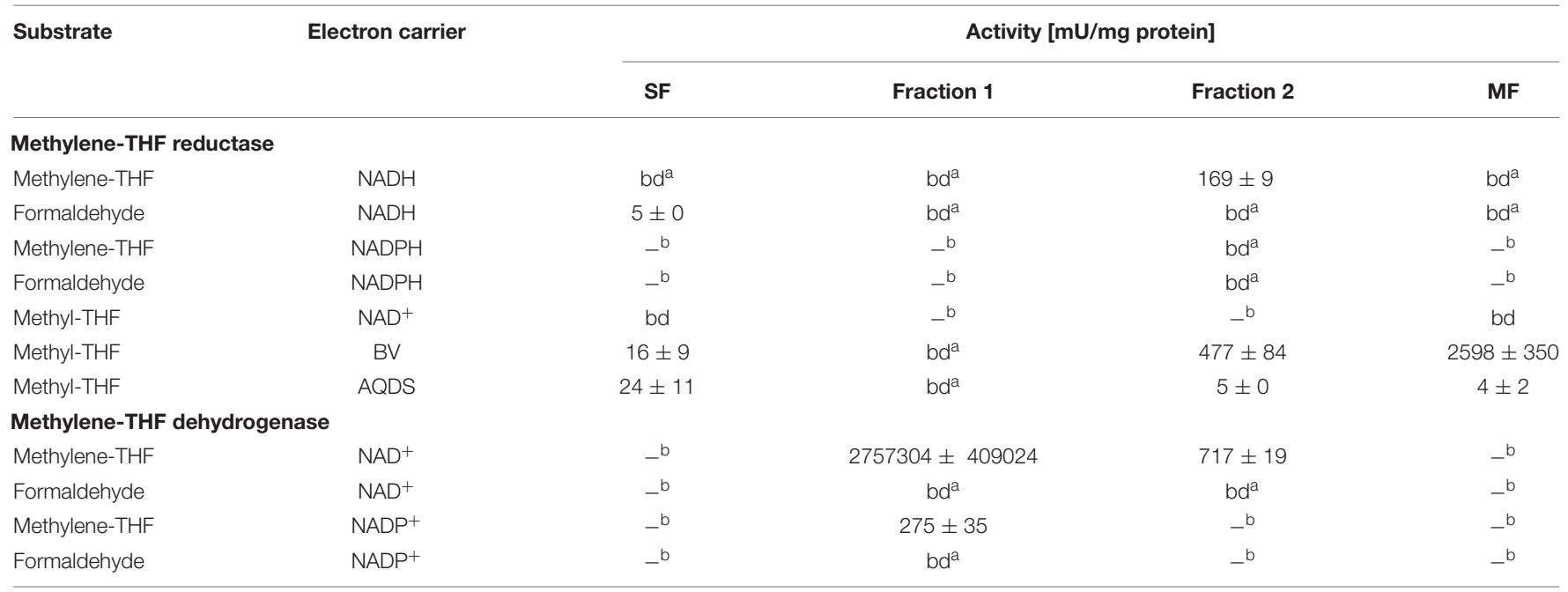

Activities were measured in soluble fraction (SF), membrane fraction (MF) or in SF separated by anion exchange chromatography with a HiTrapQ column (Fraction 1 , elution with $200 \mathrm{mM} \mathrm{NaCl}$ and Fraction 2, elution with $1 \mathrm{M} \mathrm{NaCl}$ ). This was done to separate and individually assay the activities of MTHFR and MTHFD. All enzyme assays were performed in triplicates and are given in $m \cup$ per $m g$ protein. bd $d^{a}$, below detection limit ( $<1 \mathrm{mU}$ per $\mathrm{mg}$ protein). $-^{b}$, not measured. 
TABLE 3 | Activities of formate dehydrogenase and hydrogenase measured with various electron acceptors in the soluble and the membrane fraction of cells grown syntrophically with acetate.

\begin{tabular}{lccc}
\hline & Electron carrier & SF & MF \\
\hline Formate DH & AQDS & $554 \pm 27$ & $283 \pm 36$ \\
& BV & $12234 \pm 1161$ & $1866 \pm 205$ \\
& NAD $^{+}$ & $5 \pm 2$ & bd $^{\mathrm{a}}$ \\
Hydrogenase & Fdox & $\mathrm{bd}^{\mathrm{a}}$ & $\mathrm{bd}^{\mathrm{a}}$ \\
& $\mathrm{AQDS}$ & $14 \pm 2$ & $254 \pm 57$ \\
& $\mathrm{BV}$ & $418 \pm 40$ & $1576 \pm 116$ \\
& $\mathrm{NAD}$ & $248 \pm 34$ & $109 \pm 28$ \\
NADH:acceptor oxidoreductase & Fdox & $\mathrm{bd}^{\mathrm{a}}$ & $\mathrm{bd}^{\mathrm{a}}$ \\
& AQDS & $95 \pm 2$ & $\mathrm{bd}^{\mathrm{a}}$ \\
\hline
\end{tabular}

An NADH: acceptor oxidoreductase was measured with AQDS. Activities were measured in soluble fraction (SF), membrane fraction (MF). All enzyme assays were performed in triplicates and are given in $m U$ per $m g$ protein. bda ${ }^{a}$, below detection limit ( $<1 \mathrm{mU}$ per mg protein).

completely so far is A. woodii. In this organism, the energyconserving enzyme system is the Rnf complex which generates a sodium ion gradient by oxidation of reduced $\mathrm{Fd}$ with $\mathrm{NAD}^{+}$, thus driving ATP formation (Biegel et al., 2009, 2011; Biegel and Müller, 2010). However, T. phaeum, like M. thermoacetica, does not contain genes for an Rnf complex in its genome. Another enzyme which was examined as a potential candidate participating in energy conservation is MTHFR. During acetogenesis, the MTHFR reduces methylene-THF to methyl-THF and uses electrons at a potential of $-200 \mathrm{mV}$ which can be delivered by NADH $\left[\mathrm{E}_{0}{ }^{\prime}\left(\mathrm{NAD}^{+} / \mathrm{NADH}\right)=-320 \mathrm{mV}\right]$ in an exergonic reaction (Schuchmann and Müller, 2014). Indeed, activity of the MTHFR with methylene-THF and NADH was observed in the soluble fraction 2. At first sight, this might appear as evidence that MTHFR is $\mathrm{NAD}^{+}$-dependent. Considering the presence of an NADH:AQDS oxidoreductase, this could also mean that $\mathrm{NADH}$ is oxidized with quinones or other yet unknown electron acceptors by an NADH:acceptor oxidoreductase (Figure 5). It was suggested that MTHFR could have a bifurcating function and could couple the reduction of $\mathrm{Fd}_{\mathrm{ox}}$ with $\mathrm{NADH}$ to the reduction of methylene-THF. The $\Delta \mathrm{G}_{0}$ ' of the total reaction would be -12 to $+2 \mathrm{~kJ}$ per mole, depending on the redox potential of the ferredoxin (Köpke et al., 2010; Schuchmann and Müller, 2014). The concept was disproven in M. thermoacetica (Mock et al., 2014), and also in the present study such a bifurcating reaction with $\mathrm{NADH}$ and $\mathrm{Fd}_{\mathrm{ox}}$ was not observed. Instead, the observed activity with $\mathrm{NADH}$ and methylene-THF can be interpreted as a combined reaction of $\mathrm{NADH}$ :acceptor oxidoreductase and MTHFR, i.e., electron transfer from NADH via quinones to methylene-THF. Comparison of MTHFR of M. thermoacetica with MTHFR of $T$. phaeum shows high similarity of 55 to $66 \%$ (Table 1), but also the whole gene cluster exhibits a similar organization (Figure 4). MTHFR consists of two subunits MetV and MetF whose genes are located next to genes of a hydrogenase. Different from $M$. thermoacetica where all $h d r A B C$-genes for the three subunits of the HdrABC complex are located in the same gene cluster, in T. phaeum only $h d r A$ is located in the metFV-gene cluster. Genes $h d r B$ and $h d r C$ are located next to genes for a putatively periplasmically oriented formate dehydrogenase in a separate gene cluster. Genes $h d r B$ and $h d r C$ were constitutively expressed during growth with all substrates employed. This indicates that the HdrABC complex functions as a linker between MTHFR and the quinone pool during methylene-THF oxidation and reduction. It was proposed for $M$. thermoacetica that the MTHFR reaction can be coupled to a complex containing Ech hydrogenase plus formate dehydrogenase, similar to the formate hydrogenlyase complex of E. coli (Mock et al., 2014). However, no biochemical evidence was provided yet for this concept with M. thermoacetica (Mock et al., 2014). During growth with hydrogen $/ \mathrm{CO}_{2}$, genes coding for a formate hydrogenlyase system were expressed in T. phaeum which were not expressed during growth with formate or acetate. It was proposed that the formate hydrogenlyase system of $E$. coli could couple reduction of $\mathrm{CO}_{2}$ with hydrogen with the formation of a proton gradient via the membranous HyfBDF subunits (Andrews et al., 1997). Expression of this gene cluster was observed before with T. phaeum during growth with ethanol or ethanolamine in axenic cultures (Keller et al., 2019). Under these conditions, $\mathrm{CO}_{2}$ reduction via the WLP is used as a sink for electrons derived from ethanol or ethanolamine oxidation to acetate. Under standard conditions, the reduction of $\mathrm{CO}_{2}$ to formate with electrons from hydrogen is slightly endergonic which makes it implausible that energy is conserved in this step. During growth with formate, the genes for formate hydrogenlyase system are not expressed, indicating that this system is responsible only for $\mathrm{CO}_{2}$-fixation and not for energy conservation. The energy conserving systems during acetogenesis are still unknown. The genes for Ech hydrogenase (Tph_c21310-21360) as a putatively proton-translocating enzyme system are expressed during all growth conditions. Thus this enzyme system is a possible candidate for energy conservation. However, no hydrogenase activity could be measured with $\mathrm{Fd}_{\mathrm{ox}}$ and hydrogen. A formate dehydrogenase whose gene (Tph_c08060) is located in a gene cluster together with genes of a NADH:quinone oxidoreductase (Tph_c08040- Tph_c08050) was present during growth with formate. The electrons derived in this reaction could be coupled via a quinone pool to the reduction of methylene-THF (Figure 5). However, at least one more formate dehydrogenase needs to be present to deliver low-potential electrons for the $\mathrm{CO}$ dehydrogenase. A possible candidate is the constitutively present Tph_c18420.

\section{Syntrophic Acetate Oxidation}

In the direction of acetate oxidation, MTHFR poses an energetic barrier as it releases electrons at a redox potential of $-200 \mathrm{mV}$, which cannot be transferred directly to NADH $(-320 \mathrm{mV})$. This thermodynamic situation is comparable to ethanol oxidation with $\mathrm{NAD}^{+}$by alcohol dehydrogenase and is thus hardly possible at high product concentrations (Schmidt et al., 2014). However, the MTHFR in T. phaeum appears to be $\mathrm{NAD}^{+}$-independent, at least in the direction of methyl-THF oxidation. For growth of $T$. phaeum with hydrogen $/ \mathrm{CO}_{2}$, it was suggested that MTHFR could be linked 


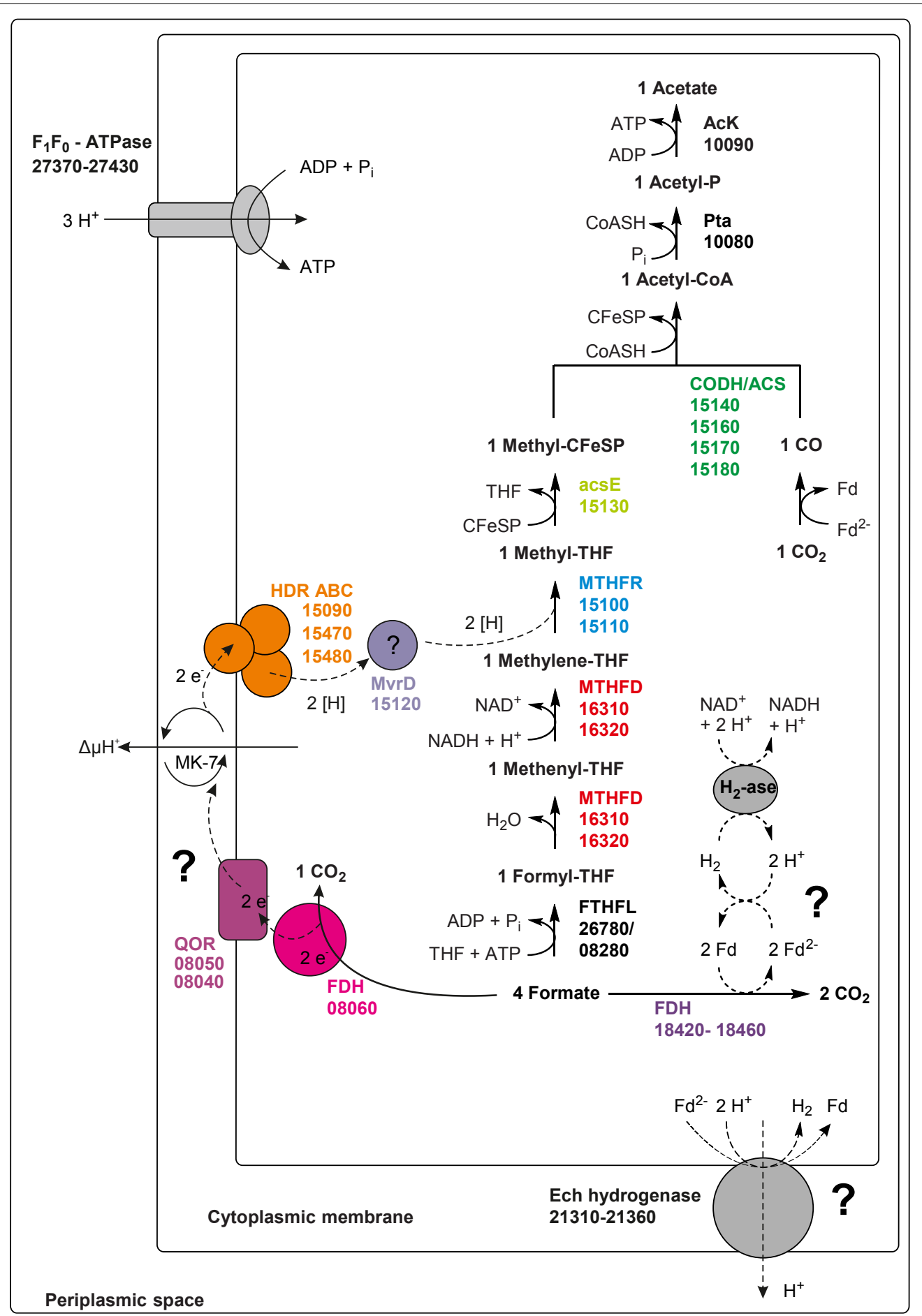

FIGURE 5 | Proposed pathway of formate utilization in T. phaeum. Colored squares and circles represent key enzyme systems using the same color coding as in Figure 4. Numbers represent the IMG gene locus tags of proteome-identified enzyme systems. Abbreviations: FeS, iron-sulfur cluster; 4Fe-4S, four-iron-four-sulfur cluster; MoPt, molybdopterin; MK-7, menaquinone-7; Fd, ferredoxin; Fd ${ }^{2-}$, reduced ferredoxin; AcK, acetate kinase; pta, Phosphotransacetylase; CFeSP, corrinoid iron sulfur protein; CODH/ACS, carbon monoxide dehydrogenase/acetyl-coenzyme A synthase-complex; THF, tetrahydrofolate; MTHFR, methylene-THF reductase; MTHFD, methylene-THF dehydrogenase; FTHFL, formyl-THF lyase; HDR, heterodisulfide reductase; FDH, formate dehydrogenase; QOR, quinone:acceptor oxidoreductase; MvrD, methyl-viologen-reducing hydrogenase subunit D; $\mathrm{H}_{2}$-ase, hydrogenase. Question marks indicate enzyme systems, whose activities were not detected. 


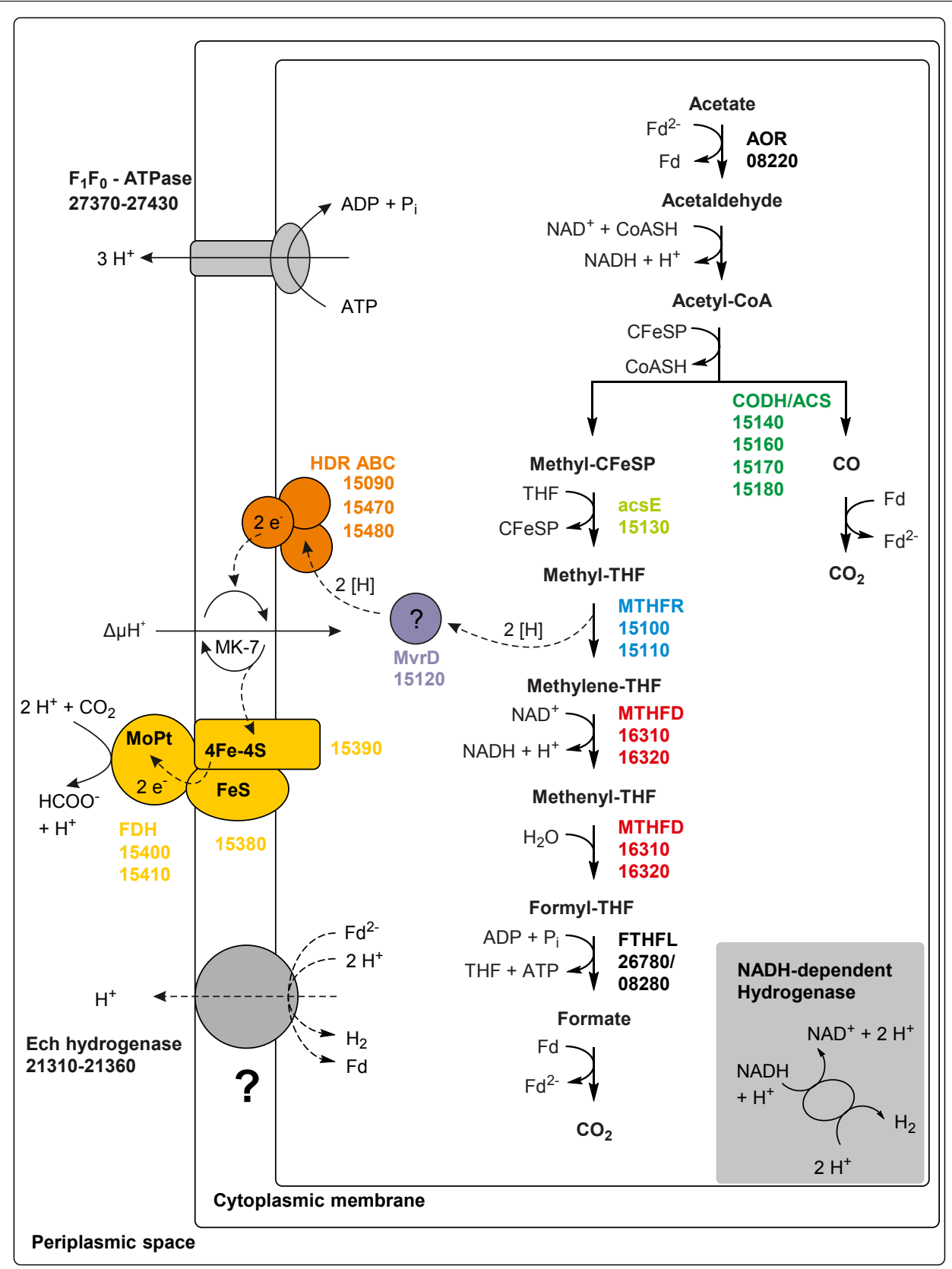

FIGURE 6 | Proposed pathway of acetate oxidation in T. phaeum. Colored squares and circles represent key enzyme systems using the same color coding as in Figure 4. Numbers represent the IMG gene locus tags of proteome-identified enzyme systems. Abbreviations: FeS, iron-sulfur cluster; 4Fe-4S, four-iron-four-sulfur cluster; MoPt, molybdopterin; MK-7, menaquinone-7; Fd, ferredoxin; Fd ${ }^{2-}$, reduced ferredoxin; AOR, aldehyde:ferredoxin oxidoreductase; CFeSP, corrinoid iron sulfur protein; CODH/ACS, carbon monoxide dehydrogenase/acetyl-coenzyme A synthase-complex; THF, tetrahydrofolate; MTHFR, methylene-THF reductase; MTHFD, methylene-THF dehydrogenase; FTHFL, formyl-THF lyase; HDR, heterodisulfide reductase; FDH, formate dehydrogenase; MvrD, methyl-viologen-reducing hydrogenase subunit D. Question marks indicate enzyme systems, whose activities were not detected.

to a quinone pool by an $\mathrm{HdrABC}$ system. The $\mathrm{HdrB}$ and $\mathrm{HdrC}$ subunits are encoded in a gene cluster together with genes for a periplasmically oriented formate dehydrogenase. This formate dehydrogenase is present only during growth with acetate, and it reveals high similarity to a previously described periplasmically oriented formate dehydrogenase in $S$. wolfei (Schmidt et al., 2013; Crable et al., 2016). In S. wolfei, this gene cluster is expressed during syntrophic butyrate oxidation. The electrons from butyryl-CoA oxidation to crotonyl-CoA have a comparably high electron potential of $\mathrm{E}_{\mathrm{o}}{ }^{\prime}=-10 \mathrm{mV}$ or $-125 \mathrm{mV}$ depending on the literature (Gustafson et al., 1986; Sato et al., 1999) and thus cannot be used directly for $\mathrm{NAD}^{+}$reduction. In $S$. wolfei, an electron transfer flavoprotein (EtfAB) carries the electrons from butyryl-CoA dehydrogenase 
to a membrane-bound FeS-containing oxidoreductase which reduces the quinone pool in the membrane (Schmidt et al., 2013; Crable et al., 2016). In T. phaeum, the MTHFR activity with BV and AQDS as artificial electron acceptors was found in washed membrane fractions indicating that MTHFR is associated with the membrane, yet not membrane-integral as it lacks transmembrane helices. Probably the enzyme whose gene is annotated as coenzyme $\mathrm{F}_{420}$-reducing hydrogenase (Tph_c15120) transfers the electrons to the HdrABC system which subsequently reduces a quinone, most likely menaquinone, as menaquinone MK-7 is the predominant quinone in T. phaeum (Hattori et al., 2000; Oehler et al., 2012). This system thus produces methylene-THF and menaquinol. The latter could then be re-oxidized at the gamma subunit of the formate dehydrogenase. The electrons are transferred to an iron-sulfur cluster-containing subunit and finally to the active site of the formate dehydrogenase (Figure 6). We show here that in vitro activity of a quinone-dependent formate dehydrogenase can be measured with BV or with AQDS as an artificial quinone. Similar enzyme assay results were obtained for hydrogenase, which is apparently also $\mathrm{NAD}^{+}$-independent, quinone-dependent and membrane bound. One potential candidate could be a complex of three hydrogenase subunits, which were constitutively present in the proteome (Figure 2, Tph_c06350 - Tph_c06370). One subunit (Tph_c06350) carries a TAT-signal sequence and another subunit (Tph_c06370) has transmembrane helices and is annotated as b-type cytochrome subunit that is most likely responsible for redox communication with menaquinone. This protein complex hence possibly resembles a membrane-bound, periplasmically oriented and quinone-dependent hydrogenase analogous to the described formate dehydrogenase. Therefore, besides formate, electrons derived from methyl-THF oxidation could alternatively be released as hydrogen via menaquinone similar to the system in S. wolfei (Crable et al., 2016). Yet, proteome data of $T$. phaeum obtained in the current study indicates, that membrane-bound formate dehydrogenase is of greater importance, as it is the only enzyme system that is almost exclusively present during syntrophic growth with acetate (Figure 2). Coupling MTHFR to the putatively periplasmically oriented formate dehydrogenase could overcome the energetic barrier that this reaction sets in the reversed WLP. However, this reaction would need to be pulled by a proton gradient and a low formate concentration. The low formate concentration can be achieved only in syntrophic cooperation with $M$. thermautotrophicus strain TM as partner that uses both formate and hydrogen as electron donors (Hattori et al., 2001). This could explain why T. phaeum has difficulties to oxidize acetate with a methanogen that uses only hydrogen as electron donor (Hattori et al., 2001). Unfortunately, formation of a proton gradient coupled to methylTHF oxidation by quenching of the fluorescent dye ACMA in inverted membrane vesicles according to Schoelmerich and Müller (2019) could not yet be demonstrated in T. phaeum (data not shown). The postulated reversed electron transport from methyl-THF to formate would require a proton gradient to be established by ATP hydrolysis. This would mean that acetate cannot be activated to acetyl-phosphate with acetate kinase as typical of the acetate-forming WLP (Schuchmann and Müller, 2014). Alternatively, acetate could be activated by an acetaldehyde oxidoreductase without ATP investment as it was described before for Clostridium ljungdahlii (Köpke et al., 2010; Bengelsdorf et al., 2013; Keller et al., 2019). The ATP thus "saved" could be partly invested into the described reversed electron transport system. In cell-free extracts of T. phaeum, the activity of acetaldehyde oxidoreductase was proven with benzyl viologen as electron acceptor in the direction of acetaldehyde oxidation (Keller et al., 2019). In the physiological direction of acetate reduction, no activity could be measured yet. A reason for this failure could be the presumably low activity of the enzyme in the direction of acetaldehyde formation. Experiments with a purified aldehyde:ferredoxin oxidoreductase (AOR) of M. thermoacetica indicate that acetate $\left(\mathrm{K}_{\mathrm{m}}=5.6 \mathrm{mM}\right)$ is turned over at an about 500 times higher $K_{m}$ than acetaldehyde $\left(\mathrm{K}_{\mathrm{m}}=10 \mu \mathrm{M}\right)$ (Huber et al., 1995). With this, an accumulation of toxic acetaldehyde inside the cell is avoided. Attempts were made to purify the acetaldehyde:oxidoreductase of T. phaeum, however, no active protein fraction was obtained so far (data not shown).

Recently, a genomic comparison of the five AOB sequenced to that date, i.e., C. ultunense (Schnürer et al., 1996), T. phaeum (Hattori et al., 2000), Pseudothermotoga lettingae (Balk et al., 2002), S. schinkii (Westerholm et al., 2010) and Tepidanaerobacter acetatoxydans (Westerholm et al., 2011) was published (Manzoor et al., 2018). This study revealed that not all SAOBs use the WLP. Even P. lettingae and C. ultunense lack central enzymes of the WLP such as the CODH/ACS and MTHFR in their genomes, thus more than one pathway of acetate oxidation must exist (Manzoor et al., 2018). Only S. schinkii and T. phaeum encode the entire WLP, but $S$. schinkii is not able to grow with hydrogen $/ \mathrm{CO}_{2}$ or formate. According to Manzoor et al. (2018), T. phaeum is the only SAOB that encodes a formate hydrogenlyase system and only $S$. schinkii encodes also a membrane-bound formate dehydrogenase (Ssch_14900031490006). The periplasmically oriented formate dehydrogenase and the formate hydrogenlyase complex, both representing two membrane-bound enzyme systems, could be the key for the reversibility of the WLP in T. phaeum. However, the exact mechanism of these systems is unclear, and it is indispensable to provide further biochemical data additional to genomic and proteomic studies to support the proposed fermentation pathways.

\section{DATA AVAILABILITY STATEMENT}

The raw data supporting the conclusion of this manuscript will be made available by the authors, without undue reservation, to any qualified researcher.

\section{AUTHOR CONTRIBUTIONS}

AK conducted the experiments designed by AK and NM. AK, $\mathrm{NM}$, and BS wrote and approved the final manuscript. 


\section{FUNDING}

This work was funded by the Deutsche Forschungsgemeinschaft, project number MU 3953/1-1.

\section{ACKNOWLEDGMENTS}

We thank Julia Schmidt for technical assistance and Andreas Marquardt of the Proteomics Facility of the University of Konstanz for proteome analysis. We also thank Alexander Schmidt for helpful ideas and discussions especially in the beginning of the project.

\section{REFERENCES}

Andrews, S. C., Berks, B. C., McClay, J., Ambler, A., Quail, M. A., Golby, P., et al. (1997). A 12-cistron Escherichia coli operon (hyf) encoding a putative protontranslocating formate hydrogenlyase system. Microbiology 143, 3633-3647. doi: 10.1099/00221287-143-11-3633

Balk, M., Weijma, J., and Stams, A. J. M. (2002). Thermotoga lettingae sp. nov., a novel thermophilic, methanol-degrading bacterium isolated from a thermophilic anaerobic reactor. Int. J. Syst. Evol. Microbiol. 52, 1361-1368. doi: 10.1099/ijs.0.02165-0

Bengelsdorf, F. R., Straub, M., and Dürre, P. (2013). Bacterial synthesis gas (syngas) fermentation. Environ. Technol. 34, 1639-1651. doi: 10.1080/09593330.2013. 827747

Bertsch, J., Öppinger, C., Hess, V., Langer, J. D., and Müller, V. (2015). Heterotrimeric NADH-oxidizing methylenetetrahydrofolate reductase from the acetogenic bacterium Acetobacterium woodii. J. Bacteriol. 197, 1681-1689. doi: 10.1128/JB.00048-15

Biegel, E., and Müller, V. (2010). Bacterial Na+-translocating ferredoxin:NAD+ oxidoreductase. Proc. Natl. Acad. Sci. U.S.A. 107, 18138-18142. doi: 10.1073/ pnas. 1010318107

Biegel, E., Schmidt, S., González, J., and Müller, V. (2011). Biochemistry, evolution and physiological function of the Rnf complex, a novel ion-motive electron transport complex in prokaryotes. Cell. Mol. Life Sci. 68, 613-634. doi: 10.1007/ s00018-010-0555-8

Biegel, E., Schmidt, S., and Müller, V. (2009). Genetic, immunological and biochemical evidence for a Rnf complex in the acetogen Acetobacterium woodii. Environ. Microbiol. 11, 1438-1443. doi: 10.1111/j.1462-2920.2009.01871.x

Crable, B. R., Sieber, J. R., Mao, X., Alvarez-Cohen, L., Gunsalus, R., Ogorzalek Loo, R. R., et al. (2016). Membrane complexes of Syntrophomonas wolfei involved in syntrophic butyrate degradation and hydrogen formation. Front. Microbiol. 7:1795. doi: 10.3389/fmicb.2016.01795

Enoki, M., Shinzato, N., Sato, H., Nakamura, K., and Kamagata, Y. (2011). Comparative proteomic analysis of Methanothermobacter themautotrophicus $\Delta \mathrm{H}$ in pure culture and in co-culture with a butyrate-oxidizing bacterium. PLoS One 6:e24309. doi: 10.1371/journal.pone.0024309

Gersonde, K., Trittelvitz, E., Schlaak, H.-E., and Stabel, H.-H. (1971). The influence of the dimerisation on the stoichiometry of the active center in ferredoxin from Clostridium pasteurianum. Eur. J. Biochem. 22, 57-65. doi: 10.1111/j.14321033.1971.tb01514.x

Gustafson, W. G., Feinberg, B. A., and McFarland, J. T. (1986). Energetics of $\beta$-oxidation. Reduction potentials of general fatty acyl-CoA dehydrogenase, electron transfer flavoprotein and fatty acyl-CoA substrates. J. Biol. Chem. 261, 7733-7741.

Hattori, S., Galushko, A. S., Kamagata, Y., and Schink, B. (2005). Operation of the CO dehydrogenase/acetyl coenzyme a pathway in both acetate oxidation and acetate formation by the syntrophically acetate-oxidizing bacterium Thermacetogenium phaeum. J. Bacteriol. 187, 3471-3476. doi: 10.1128/jb.187. 10.3471-3476.2005

Hattori, S., Kamagata, Y., Hanada, S., and Shoun, H. (2000). Thermacetogenium phaeum gen. nov., sp. nov., a strictly anaerobic, thermophilic, syntrophic

\section{SUPPLEMENTARY MATERIAL}

The Supplementary Material for this article can be found online at: https://www.frontiersin.org/articles/10.3389/fmicb. 2019.02785/full\#supplementary-material

TABLE S1 | Total Proteomics analysis of cells of Thermacetogenium phaeum grown with formate (Formiat), hydrogen/ $\mathrm{CO}_{2}\left(\mathrm{H}_{2} \mathrm{CO}_{2}\right)$, or acetate (Acetat). Shown are the results of mass spectrometry analysis using the Proteome Discoverer software (Thermo Fisher). Identified proteins are presented along with the accession numbers of their genes as well as the MASCOT-scores and the area values of the Proteome Discoverer software (Thermo Fisher). Area values were used for semi-quantitatively presenting the abundances of the identified proteins. The data for cells grown with acetate are the same as used in (Keller et al., 2019).

acetate-oxidizing bacterium. Int. J. Syst. Evol. Microbiol. 50(Pt 4), 1601-1609. doi: 10.1099/00207713-50-4-1601

Hattori, S., Luo, H., Shoun, H., and Kamagata, Y. (2001). Involvement of formate as an interspecies electron carrier in a syntrophic acetate-oxidizing anaerobic microorganism in coculture with methanogens. J. Biosci. Bioeng. 91, 294-298. doi: $10.1263 /$ jbb. 91.294

Hess, V., Schuchmann, K., and Müller, V. (2013). The ferredoxin:NAD+ oxidoreductase (Rnf) from the acetogen Acetobacterium woodii requires $\mathrm{Na}+$ and is reversibly coupled to the membrane potential. J. Biol. Chem. 288, 31496-31502. doi: 10.1074/jbc.M113.510255

Huang, H., Wang, S., Moll, J., and Thauer, R. (2012). Electron Bifurcation Involved in the Energy Metabolism of the acetogenic bacterium Moorella thermoacetica growing on glucose or H2 plus CO2. J. Bacteriol. 194, 3689-3699. doi: 10.1128/ jb.00385- 12

Huber, C., Skopan, H., Feicht, R., White, H., and Simon, H. (1995). Pterin cofactor substrate specificity, and observations on the kinetics of the reversible tungstencontaining aldehyde oxidoreductase from Clostridium thermoaceticum. Arch. Microbiol. 164, 110-118. doi: 10.1007/s002030050242

Keller, A., Schink, B., and Müller, N. (2019). Alternative pathways of acetogenic ethanol and methanol degradation in the thermophilic anaerobe Thermacetogenium phaeum. Front. Microbiol. 10:423. doi: 10.3389/fmicb.2019. 00423

Köpke, M., Held, C., Hujer, S., Liesegang, H., Wiezer, A., Wollherr, A., et al. (2010). Clostridium ljungdahlii represents a microbial production platform based on syngas. Proc. Natl. Acad. Sci. U.S.A. 107, 13087-13092. doi: 10.1073/pnas. 1004716107

Laemmli, U. K. (1970). Cleavage of structural proteins during the assembly of the head of bacteriophage T4. Nature 227, 680-685. doi: 10.1038/227680a0

Liu, C., Zachara, J. M., Foster, N. S., and Strickland, J. (2007). Kinetics of Reductive dissolution of hematite by bioreduced anthraquinone-2,6-disulfonate. Environ. Sci. Technol. 41, 7730-7735. doi: 10.1021/es070768k

Luo, H.-W., Zhang, H., Suzuki, T., Hattori, S., and Kamagata, Y. (2002). Differential expression of methanogenesis genes of Methanothermobacter thermoautotrophicus (formerly Methanobacterium thermoautotrophicum) in pure culture and in cocultures with fatty acid-oxidizing syntrophs. Appl. Environ. Microbiol. 68, 1173-1179. doi: 10.1128/aem.68.3.1173-1179.2002

Manzoor, S., Schnürer, A., Bongcam-Rudloff, E., and Müller, B. (2018). Genomeguided analysis of Clostridium ultunense and comparative genomics reveal different strategies for acetate oxidation and energy conservation in syntrophic acetate-oxidising bacteria. Genes 9:E225. doi: 10.3390/genes 9040225

McKellar, R. C., and Sprott, G. D. (1979). Solubilization and properties of a particulate hydrogenase from Methanobacterium strain G2R. J. Bacteriol. 139, 231-238.

Mock, J., Wang, S., Huang, H., Kahnt, J., and Thauer, R. K. (2014). Evidence for a hexaheteromeric methylenetetrahydrofolate reductase in Moorella thermoacetica. J. Bacteriol. 196, 3303-3314. doi: 10.1128/JB.01839-14

Neuhoff, V., Arold, N., Taube, D., and Ehrhardt, W. (1988). Improved staining of proteins in polyacrylamide gels including isoelectric focusing gels with clear background at nanogram sensitivity using Coomassie brilliant blue G-250 and R-250. Electophoresis 9, 255-262. doi: 10.1002/elps.1150090603 
Oehler, D., Poehlein, A., Leimbach, A., Müller, N., Daniel, R., Gottschalk, G., et al. (2012). Genome-guided analysis of physiological and morphological traits of the fermentative acetate oxidizer Thermacetogenium phaeum. BMC Genomics 13:723. doi: 10.1186/1471-2164-13-723

Rosner, B. M., and Schink, B. (1995). Purification and characterization of acetylene hydratase of Pelobacter acetylenicus, a tungsten iron-sulfur protein. J. Bacteriol. 177, 5767-5772. doi: 10.1128/jb.177.20.5767-5772.1995

Sato, K., Nishina, Y., Setoyama, C., Miura, R., and Shiga, K. (1999). Unusually high standard redox potential of Acrylyl-CoA/Propionyl-CoA couple among Enoyl-CoA/Acyl-CoA couples: a reason for the distinct metabolic pathway of propionyl-CoA from longer Acyl-CoAs. J. Biochem. 126, 668-675. doi: 10.1093/ oxfordjournals.jbchem.a022501

Schmidt, A., Frensch, M., Schleheck, D., Schink, B., and Müller, N. (2014). Degradation of acetaldehyde and its precursors by Pelobacter carbinolicus and P. acetylenicus. PLoS One 9:e115902. doi: 10.1371/journal.pone.0115902

Schmidt, A., Müller, N., Schink, B., and Schleheck, D. (2013). A proteomic view at the biochemistry of syntrophic butyrate oxidation in Syntrophomonas wolfei. PLoS One 8:e56905. doi: 10.1371/journal.pone.0056905

Schnürer, A., Schink, B., and Svensson, B. (1996). Clostridium ultunense sp. nov., a mesophilic bacterium oxidizing acetate in syntrophic association with a hydrogenotrophic methanogenic bacterium. Int. J. Syst. Bacterioleriol. 46, 1145-1152. doi: 10.1099/00207713-46-4-1145

Schoelmerich, M. C., and Müller, V. (2019). Energy conservation by a hydrogenasedependent chemiosmotic mechanism in an ancient metabolic pathway. Proc. Natl. Acad. Sci. U.S.A. 116, 6329-6334. doi: 10.1073/pnas.1818580116

Schuchmann, K., and Müller, V. (2014). Autotrophy at the thermodynamic limit of life: a model for energy conservation in acetogenic bacteria. Nat. Rev. Microbiol. 12, 809-821. doi: 10.1038/nrmicro3365

Shi, Z., Zachara, J. M., Shi, L., Wang, Z., Moore, D. A., Kennedy, D. W., et al. (2012). Redox reactions of reduced flavin mononucleotide (FMN), riboflavin (RBF), and anthraquinone-2,6-disulfonate (AQDS) with ferrihydrite and lepidocrocite. Environ. Sci. Technol. 46, 11644-11652. doi: 10.1021/es301544b
Timmers, P. H. A., Vavourakis, C. D., Kleerebezem, R., Damsté, J. S. S., Muyzer, G., Stams, A. J. M., et al. (2018). Metabolism and occurrence of methanogenic and sulfate-reducing syntrophic acetate oxidizing communities in haloalkaline environments. Front. Microbiol. 9:3039. doi: 10.3389/fmicb.2018.03039

Wang, S., Huang, H., Kahnt, J., and Thauer, R. K. (2013). A reversible electronbifurcating ferredoxin- and NAD-dependent [FeFe]-hydrogenase (HydABC) in Moorella thermoacetica. J. Bacteriol. 195, 1267-1275. doi: 10.1128/JB. 02158-12

Westerholm, M., Roos, S., and Schnürer, A. (2010). Syntrophaceticus schinkii gen. nov., sp. nov., an anaerobic, syntrophic acetate-oxidizing bacterium isolated from a mesophilic anaerobic filter. FEMS Microbiol. Lett. 309, 100-104. doi: 10.1111/j.1574-6968.2010.02023.x

Westerholm, M., Roos, S., and Schnürer, A. (2011). Tepidanaerobacter acetatoxydans sp. nov., an anaerobic, syntrophic acetate-oxidizing bacterium isolated from two ammonium-enriched mesophilic methanogenic processes. Syst. Appl. Microbiol. 34, 260-266. doi: 10.1016/j.syapm.2010.11.018

Zhang, Y., and Gladyshev, V. N. (2005). An algorithm for identification of bacterial selenocysteine insertion sequence elements and selenoprotein genes. Bioinformatics 21, 2580-2589. doi: 10.1093/bioinformatics/bti400

Ziegenhorn, J., Senn, M., and Bücher, T. (1976). Molar absorptivities of betaNADH and beta-NADPH. Clin. Chem. 22, 151-160.

Conflict of Interest: The authors declare that the research was conducted in the absence of any commercial or financial relationships that could be construed as a potential conflict of interest.

Copyright (c) 2019 Keller, Schink and Müller. This is an open-access article distributed under the terms of the Creative Commons Attribution License (CC BY). The use, distribution or reproduction in other forums is permitted, provided the original author(s) and the copyright owner(s) are credited and that the original publication in this journal is cited, in accordance with accepted academic practice. No use, distribution or reproduction is permitted which does not comply with these terms. 